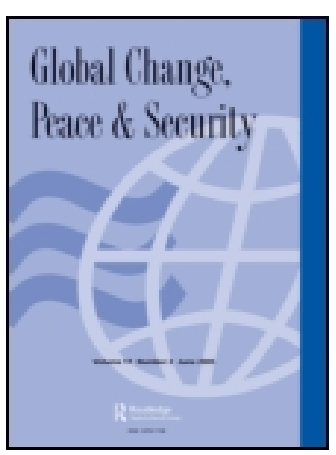

Global Change, Peace \& Security

formerly Pacifica Review: Peace, Security \& Global Change

ISSN: 1478-1158 (Print) 1478-1166 (Online) Journal homepage: http://www.tandfonline.com/loi/cpar20

\title{
The uses and misuses of dialogue
}

\section{Jeremy Salt}

To cite this article: Jeremy Salt (2012) The uses and misuses of dialogue, Global Change, Peace \& Security, 24:1, 183-188, DOI: 10.1080/14781158.2012.641290

To link to this article: https://doi.org/10.1080/14781158.2012.641290

央 Published online: 30 Jan 2012.

Submit your article to this journal $\widetilde{ }$

III Article views: 83 


\title{
REVIEW ESSAY
}

\section{The uses and misuses of dialogue}

\author{
Jeremy Salt* \\ Department of Political Science, Bilkent University, Turkey
}

Michális S. Michael and Fabio Petito, eds., Civilizational Dialogue and World Order. The Other Politics of Cultures, Religions and Civilizations in International Relations (London: Palgrave Macmillan, 2009).

'Civilisation' as a tool of power has been a constant in world history since the 'discovery' of new worlds by Portuguese, Spanish, Dutch and British adventurers. 'Discovery' conferred ownership and 'civilisation' justified it. The classification of humans into descending categories of civilised, savages and barbarians was a form of moral stratification. Beginning as a neologism from its Latin roots, civilisation moved forward with "western' ${ }^{1}$ explorers and armies wherever they set foot. The implicit message was not what we are doing to you but what we are doing for you. Inevitably, the invaded and colonised fought back and sometimes had the numbers to inflict significant defeats. In Muslim territories, because there was no nation, and displaced rulers who left behind no structure of government, Islam had to be the rallying point. In south-eastern Europe, and amongst the Christians of the Ottoman domains, it was identified as the central source of the problems they were experiencing under 'Muhammadan rule'. No wonder, then, at the high point of imperialism, in a deeply evangelistic age, that the Scottish orientalist Sir William Muir could write that 'the sword of Mahomet, and the Coran, are the most stubborn enemies of Civilisation, Liberty and Truth which the world has yet known'. ${ }^{2}$ Muir, Stanley Lane-Poole and Ignaz Goldziher were among the orientalists of the late nineteenth century who were the authorities for the scholars who dominated the field for much of the twentieth. The most influential of them, at least in Britain and the United States, were D.S. Margoliouth, H.A.R. (Hamilton) Gibb, Alfred Guillaume, A.J. Arberry, Bernard Lewis, Marshall Hodgson, Wilfred Cantwell Smith, Elie Kedourie and Stanford Shaw. Of those named here, only Bernard Lewis (born in 1916) is still living, and, until very recently at least, still turning out one book after another. As a link not just between the scholarship of the late nineteenth century but its culture, it is not surprising that Lewis also hands civilisation to his readers as a means of understanding the problems of the Arab and Muslim worlds (but not of the problems of the 'west'). What is somewhat surprising is that nowhere in this book do any of the authors point out that the 'clash of civilisations' belongs not to Samuel P. Huntington but to Lewis.

Muir portrayed Islam as an inert mass blocking progress by its sheer weight ('the nations may advance in civilisation and morality, in philosophy, science and the arts; but Islam stands still. And thus stationary, so far as the lessons of this history avail, it will remain' ${ }^{3}$ ): as he calls it

\footnotetext{
*Email: jeremy@bilkent.edu.tr

1 Although some take the West or 'the West' as a given, I do not and prefer to neutralise its authority by putting it in single quotes and using a lower case ' $w$ '.

2 Sir William Muir, The Life of Mahomet: From Original Sources (London: Smith, Elder, 1878), 535.
}

ISSN 1478-1158 print/ISSN 1478-1166 online

(C) 2012 Taylor \& Francis

http://dx.doi.org/10.1080/14781158.2012.641290

http://www.tandfonline.com 
'the greatest enemy of Civilisation', he clearly did not regard it as civilisation in its own right. By contrast, writing in the 1960s, Lewis puts the problems the 'west' is experiencing in the Middle East in the context of two civilisations in active conflict. He summarises 'westernisation' and the self-perception of 'we of the West' in the following way:

To be like us is good; to be unlike us is bad. To be more like us is to improve; to become less like us is to deteriorate. It is not necessarily so. When civilisations clash there is one that prevails and one that is shattered. Idealists and ideologues may talk glibly of 'a marriage of the best elements' from both sides but the usual result of such an encounter is a cohabitation of the worst. ${ }^{4}$

The civilisation on the receiving end of this collision finally reacts 'against the impact of alien forces that have dominated, dislocated and transformed it'. 5 Accordingly, 'we shall be better able to understand this situation if we view the present discontents of the Middle East not as a conflict between states or nations but as a clash between civilisations' ${ }^{6}$ What Lewis meant by 'this situation' was the nationalist euphoria surging across the Middle East and threatening 'western interests' at critically important points. Nearly two centuries of blood-drenched history were finally coming to an end. Countless thousands of Algerians, Egyptians, Sudanese, Syrians, Palestinians and Iraqis had died in the struggle to drive the French and the British out of their lands. Their cities and towns had been bombarded from the sea, strafed from the air and shelled from the ground, yet Bernard Lewis calls on his readers to believe that what they are seeing before their eyes is not something as concrete as the last stage of a protracted liberation struggle but an amorphous 'clash between civilisations'. Nearly three decades later Islam has replaced Arab nationalism as the dominant paradigm of resistance to 'western' intervention, but the explanation remains the same:

It should be clear that we are facing a mood and a movement far transcending the level of issues and policies and government that pursue them. This is no less than a clash of civilisations - that perhaps irrational but surely historic reaction of an ancient rival against our Judaeo-Christian heritage, our secular present and the worldwide expansion of both. ${ }^{7}$

In 1993 Huntington published his interesting article in Foreign Policy, ${ }^{8}$ followed shortly afterwards by a book on the same theme. His map of the world is filled with civilisational fault and fracture lines. 'Islam's bloody borders' is the phrase he uses for the demarcation line between Islamic and 'western' civilisations. The alert reader would surely have to wonder about this. For a start, religions do not fix borders, states do, and while the Ottoman Empire fixed borders in the fifteenth and sixteenth centuries, its capacity to maintain them quickly drained away. From the eighteenth century down to the early years of the twentieth, in the Middle East and Africa (south, west, east and north), in the Balkans, the Caucasus and Central Asia, borders were fixed by the governments of Britain, France, Austria-Hungary, Russia and newer players in the imperial game. The blood shed along these borders was overwhelmingly Muslim, if blood must have a religion. Overall, though, the attack on the Twin Towers and the Pentagon in 2001 seemed to confirm that both Lewis and Huntington were right and Francis Fukuyama was wrong. History had not quite ended: a new and dangerous phase seemed to be emerging from the shadows.

An alternative position would be to see the 'clash of civilisations' line as what is called in psychological warfare a false flag operation, one, in this case, that allows specific governments, hiding behind the mask of the 'west', to avoid taking responsibility for the destructive conse-

3 Sir William Muir, Annals of the Early Caliphate: From Original Sources (London: Smith, Elder, 1883), 459.

4 Bernard Lewis, The Middle East and the West (London: Weidenfeld and Nicolson, 1963 and 1964), 43.

5 Ibid., 46.

6 Ibid., 137.

7 Bernard Lewis, 'The Roots of Muslim Rage', Atlantic Monthly (September 1990): 47-60.

8 Samuel P. Huntington, 'The Clash of Civilisations?', Foreign Affairs 72 (Summer 1993): 22-49. 
quences of their policies. The modern history of the Middle East, and indeed most of the Muslim world, teems with solid reasons for anger at the 'west', yet for Lewis none of them, not even Palestine, is convincing. If, as he says, the rage directed towards the 'west' from Muslim societies has not been brought on by the effects of 'western policies', but is the 'irrational' response of a defeated rival, basically the problem is theirs to fix.

The whole civilisational debate skates on thin ice. 'Islam' is not an object or an actor with a will of its own. It is lived by Muslims in different countries in many different ways. The rhetoric assumes that we all know whose side we are on. The positioning of 'Islam and the West' as polarised opposites has to be challenged the moment the phrase is uttered. It sits at the top of the slippery rhetorical slope that leads downhill to the 'clash of civilisations'. There is certainly no shortage of people in the 'west' who would shudder at being included in the 'we' of Bernard Lewis, George Bush and Tony Blair. They can be just as angry as Muslims at what are usually called Muslim causes. There are no civilisational 'sides' here. Civilisations (leaving aside for the moment the questions of how many there were and how to define them) have been interdependent throughout history, borrowing, teaching and learning from each. Dialogue is intrinsic to all of these exchanges. Hamilton Gibb believed that there has been 'inter-penetration' between the civilisations of the Middle East and the 'so-called Western world' even before the rise of Islam. As for the imposition of 'western' forms of government on a bewildered and resentful Middle East,

it was not Westerners who advocated the adoption of legal codes, parliamentary institutions, compulsory education and freedom of the press: all these institutions were demanded by the peoples of the East themselves ... the facts are much more complex than the oversimplification of publicists and in each country or region one must allow for local nuances or even greater divergences. ${ }^{9}$

John Hobson has written compellingly on the way humans have copied and learnt from each other throughout history. ${ }^{10}$ So has Martin Bernal, in Black Athena, which pointed to the Afro-Nilotic origins of 'western' civilisation, a theory that brought blanket condemnation by the 'classicists' down on his head ${ }^{11}$. 'Globalisation' does not belong to the contemporary age, but has been going on for centuries and probably millennia, even if, as Manfred Steger writes in Civilisational Dialogue and World Order, referring to Jan Nederveen Pieterse, its evolution until recently has been 'glacier-like' (p. 148).

Whereas dialogue ('genuine' dialogue) is based on listening, the narratives of empire are structured around telling and - ultimately - compelling. Neither the narrative nor the imperial drive has gone away even if, rather like the British towards the end of empire, America's hold on the world is visibly shrinking. Drones fire Predator missiles into Afghanistan, Pakistan, Somalia and Yemen at the command of a distant control centre. The national strategic policy of the Bush administration was based on the outright rejection of the rights of the sovereign state acknowledged in the Treaty of Westphalia. No state regarded as potentially threatening deserved to have its borders respected. The battlefield remodelling of the world in accordance with the prescriptions of the Project for the New American Century was accompanied economically by doctrines aimed at removing all barriers to the free movement of capital. The IMF and the World Bank saw to it that aid went into the investment-rich private sector, and not where it was needed in the public sector. The consequences of these doctrines included the further enrichment of the few, the further impoverishment of the many and, in recent years, the near collapse of the entire 'liberal' economic system under the weight of the greed of financial institutions, investors

9 H.A.R. Gibb, Studies on the Civilisation of Islam, ed. Stanford J. Shaw and William R. Polk (London: Routledge and Kegan Paul, 1962), 328.

10 John M. Hobson, The Eastern Origins of Western Civilisation (New York: Cambridge University Press, 2004).

11 Martin Bernal, Black Athena, Vol. 1, The Afroasiatic Roots of Classical Civilisation. The Fabrication of Ancient Greece 1785-1985 (New Jersey: Rutgers University Press, 1987) and Black Athena, Vol 2, The Archaeological and Documentary Evidence (New Jersey: Rutgers University Press, 1991). 
and speculators. The world order is working in the same way that a wheezing, broken-down, worn-out machine works.

The essays in this book are constructed around the theme of dialogue as the way ahead to solving global problems through the mechanism of an 'alliance of civilisations'. The issues are framed in a variety of ways. Fred Dallmayr explores the disruptive effects of power on dialogue. Those with it are not likely to give way to those without it just because morality, ethics, justice and the provisions of international law indicate that they should. Although the problem is acute in international relations, the worsening calamities of human history have so failed to convince states that there must be a better way of arranging their affairs than the single-minded focus on power - tenuous in itself because coercion alone is never enough to keep people in line - to get what they want. Dallmayr believes that the call for dialogue responds to 'deep-seated human needs' (p. 44). He quotes Kant, for whom the 'actual mechanism' of human inclinations as provided by Nature guaranteed 'perpetual peace'. To Swee-Hin focuses on inter-faith dialogue, which, of course, is the strong suit of Muhammad Khatami, who launched the initiative which resulted in 2001 being declared the UN Year of Dialogue (yes, not long before the planes were flown into the World Trade Center). Raffaele Marchetti locates 'civilisationism' within the political debate over globalisation. Richard Shapcott deals with 'cosmopolitanism', which implies that 'obligations to friends and neighbors - our fellow countrymen - must be balanced with obligations to strangers and to humanity and that at times, humanity must be given first priority' (p. 124).

Phillip Darby, looking at the nexus between dialogue and the 'politics of security', warns that dialogue 'is too open to co-option and that all too easily it can be pulled into the service of upholding the existing world order' (p. 131). Manfred Steger's concern is dialogue, monologue and the branding of 'American values' (p. 148), and the need to show that freedom and democracy 'are not "American values" but are common norms to be polished through cross-cultural dialogue' (p. 161). Other essays focus on terror, counter-terror and self-destruction (Ashis Nandy); relations between the Muslim world and the 'west' after 11 September 2001 (Chandra Muzaffar); openness inside dialogue (Zhang Longxi); the Mediterranean 'space' as a contested area between Europe and the Muslim world and thus between tension and dialogue (Armando Salvatore); and the thorny question of questions of history, memory and dialogue as they affect relations between Japan and China (Michael T. Seigel). All of these perspectives point in the direction of opening up and building upon dialogue as the 'alternative model for world order' (p. 63) outlined by Fabio Petito. How to get there, of course, is the problem.

Although dialogue is conceived as an open-ended process aimed at the eventual remodelling of a morally and practically dysfunctional world order, the resolution of differences between Muslim and 'western' societies is listed as a priority by the High-Level Group appointed to prepare the ground for an 'alliance of civilisations'. In this essay the 'clash of civilisations' notion has already been described as a false flag operation. As coined by Bernard Lewis, and later elaborated by Samuel Huntington, the 'clash' throws a civilisational cloak over the misdeeds not of something as ectoplasmic as 'the west' but the specific actions of 'western' governments in the Middle East and the broader Muslim world over the last two centuries. There are many parallels between then and now. In the western cultural mainstream there is the same refusal to listen. Since 11 September 2001, there has been a wilful refusal to connect up the dots between Palestine, Afghanistan, Iraq, Lebanon and the bombing of the twin towers. Now there is Somalia and the unravelling of Yemen to thicken the mixture. What Lewis and Huntington are saying, however, is that the real dots linking the Muslim world to the horrors of 11 September 2001 are youth unemployment, a Muslim propensity for violence, an inability to adapt to the modern world, and the rage and humiliation arising from the lost civilisational contest with the 'west'.

In the Middle Eastern and Muslim world context, if the 'clash' is the wrong diagnosis, can the 'dialogue' be the right cure? And, again, this is not to disparage dialogue. There are numerous 
circumstances where it is the only way ahead. It can go a long way, for example, towards overcoming the fear and ignorance which is the basis of the hatred being whipped up by Geert Wilders in the Netherlands and similarly inclined Islamophobes. However, across Europe dialogue is being outflanked by the rise of parties and movements mobilising and building a common front around the single theme of the Muslim 'threat' to European culture. It is rapidly becoming the dominant pan-European issue. The signs that the fringe view is now right in the mainstream include the Swiss referendum favouring a ban on the construction of minarets (recent polls indicate that the Swiss also support the deportation of foreigners found guilty of committing not just serious crimes but petty ones ${ }^{12}$ ); the electoral successes of the Sweden Democrats and Wilders' own Dutch Freedom Party; the formation of a new anti-Muslim German political party, Der Freiheit (Freedom), and the establishment of similar parties elsewhere; French and Belgian proposals to ban the wearing of the full face veil in public; the negative comments about Muslim migrants by the German banker Thilo Sarrazin (who also spoke of a common Jewish gene); and Angela Merkel's recent statement that multiculturalism had been a 'total failure' in Germany. The recent summary expulsion of Roma by the Sarkozy government indicates the potential of antimigrant feeling to overflow in the direction of anyone considered an outsider. Nor are these phenomena confined to Europe. In Australia, for example, during the recent national election campaign, both the Prime Minister, Julia Gillard, and the leader of the opposition, Tony Abbott, chased votes on the basis of taking a tough line with illegal immigrants, including refugees and asylum seekers. The proposals for 'processing' these 'queue jumpers' at 'detention centres' inside Australia as well as offshore effectively continue the hard-line policies of the previous Howard government.

In the Netherlands the decision to prosecute Wilders for stirring up hatred and discrimination is a tacit admission that dialogue has its limits. Wilders and those who think like him are not interested in dialogue. Their goal is the suppression if not the eventual obliteration of Muslim culture inside Europe, and indeed they are making use of the free speech provisions of the law to spread their incendiary doctrines. In Wilders' case the law had to be invoked to stop his manipulation of the law. In a different arena, the High-level Group of the Alliance of Civilizations talks of 'counter narratives' as a means of resolving conflict in the Middle East when the central issue is not dialogue but the wilful violation of international law by governments that have sworn themselves to uphold it. The attack on Iraq in 2003 was a clear case of premeditated and unprovoked aggression, identified even by Kofi Annan, the former UN Secretary-General, as illegal and a breach of the UN Charter. ${ }^{13}$ Several hundred thousand civilians were killed or maimed, along with perhaps a million more terrorised into taking flight into neighbouring countries. By any measure these are serious crimes. In Afghanistan, thousands of innocent people have been killed in a war that seems to have long since lost its purported focus. The victims in all these situations would like a measure of justice: if Barack Obama is serious about reaching out to the Muslim world, he would see that they get it, but as he is sanctioning the use of drone attacks that are killing civilians, he has turned himself into part of the problem. The fact that no one in government responsible for the crimes committed in Iraq or Afghanistan has been prosecuted only reinforces the Muslim view that the 'west' operates according to one set of laws and moral principles for itself and another set for everyone else. The situation in Palestine is another clear example of a state - Israel - operating outside the law, wilfully, defiantly and aggressively. In a situation where time is of the essence, where more ground is being lost every day, literally in the case of the Palestinians of the West Bank and East Jerusalem, dialogue cannot be regarded as open-ended. There must be a cut-off point, where it is concluded that dialogue has failed and that the law has to be invoked.

12 See Ian Traynor, 'Immigration: Far-right Fringe Exploits European Coalition', Guardian, November 15, 2010.

13 See Ian MacAskill and Julian Borger, 'Iraq War was Illegal and Breached UN Charter, says Annan', Guardian, September 16, 2004. 
Here we get to the heart of the problem, because states will not invoke laws that do not suit their purposes, or their friends' purposes, with powerful states structuring international organisations to make sure that they work in their favour. To be viable, to be believable, to avoid turning into a counter-distraction to the 'clash of civilisations', the Alliance of Civilisations needs to concede that there are situations in which dialogue is not or can no longer be regarded as the answer. It also must be prepared to provoke and to antagonise the powerful. It needs to speak more of what must be done rather than what 'should' be done and to come up with specific remedies for specific problems. The lopsided structure of the UN Security Council is one of them - is there any reason beyond the protection of their own interests why five countries should have a permanent seat and a veto power besides? The task ahead of the Alliance of Civilisations, along with those trying on various fronts and in various ways to establish a more balanced world, is to persuade governments and corporations that short-term loss will add up to longterm gain. There is nothing new about this. The struggle for justice is as old as history itself. War and financial collapse, as usual, are more likely than moral persuasion to convince the powerful that there must be a better way to run the world, but for the rest of us there is no choice but to keep rolling the Sisyphean boulder up the world in the hope that one day it will reach the summit and stay there.

\section{Note on contributor}

Jeremy Salt teaches the history of the modern Middle East in the Department of Political Science, Bilkent University, Ankara. He has previously taught at Bosporus University in Istanbul and the University of Melbourne. His publications include The Unmaking of the Middle East: A History of Western Disorder in Arab Lands (Berkeley, CA: University of California Press, 2008) and Imperialism, Evangelism and the Ottoman Armenians 1878-1896 (London: Frank Cass, 1993), plus numerous articles in journals such as Middle Eastern Studies, Third World Quarterly, Current History, The Muslim World, Journal of Palestine Studies and Middle East Policy. 